\author{
파종기에 따른 사료용 피의 생육, 수량 및 사료가치에 관한 연구 \\ 이정준 ${ }^{1} *$. 김정곤 ${ }^{1} \cdot$ 성병열 ${ }^{1} \cdot$ 송태화 ${ }^{2} \cdot$ 박태선 $^{3}$ \\ 1사) 한국맥류산업발전연구원, ${ }^{2}$ 국립식량과학원 벼맥류부, ${ }^{3}$ 국립식량과학원
}

\title{
Studies on Growth, Forage Yield, and Nutritive Value according to Different Seeding Dates of Barnyard Millet
}

\author{
Jung-Joon Lee ${ }^{1 *}$, Jung-Gon Kim¹, Byung-Ryul Sung ${ }^{1}$, Tae-Hwa Song², Tae-Sun Park ${ }^{3}$ \\ ${ }^{1}$ Korean Wheat and Barley Industry Development Institute, Suwon 441-857, Korea, ${ }^{2}$ Rice and Winter Cereal Crop, NICS, \\ RDA, Iksan 557-080, Korea, ${ }^{3}$ National Institute of Crop Science, RDA, Suwon 441-857, Korea
}

\begin{abstract}
These experiments are being conducted to obtain data of plant height, panicle length, heading date, number of culm, and fresh and dry weight, crude protein, acid detergent fiber(ADF), neutral detergent fiber (NDF), total digestible nutrients (TDN) by six times seeding of 10 days interval ranging from May 1st to June 21st for two types of barnyard millet from the Suwon area in Korea. In the early-heading type, IT 170609 (Echinochloa crus-galli), the plant height and the number of culm per square meters are decreased by late seeding relatively, and heading date is 7 to 10 days earlier than the late seeding. And the dry weight of forage is rapidly decreased after the June 11th seeding. In the late-heading type, IT 195422 (Echinochloa frumentacea), the plant height and the number of culm per square meters are also decreased by late seeding relatively, and heading date is about 13 days earlier than late seeding. The dry weight of forage was rapidly decreased after the June 11th seeding. In both two types, the nutritive value of ADF, NDF, and TDN are not changed by late seeding, but crude protein is increased by late seeding. The TDN yields of late-heading type, IT 195400, show average amounts in the June 1st seeding, but the TDN yield of early-heading type, IT 170606, indicate safety amounts of dry weight to the March 21st seeding. And these data are available for cropping systems, cultivating barnyard millet in summer and cereals for forage in winter, to get high production of forage in Korea. (Key words : Barnyard millet, Seeding date, Forage yield, Nutritive value)
\end{abstract}

\section{I. 서 론}

국제 사료가격의 상승으로 국내 축산농가는 조사료 생산 에 많은 관심을 가지고 있으며 특히 우리나라와 같은 답리 작 재배지가 많은 특수성 때문에 단기에 생육이 왕성한 사 료용 피의 관심이 높아지고 있다. 다량의 조사료 생산을 위해서는 품종의 선택, 조생 및 만생의 생태형, 지역에 따 른 파종기의 조만이 Biomass 생산에 지대한 영향을 끼친다. 피는 건조하거나 강우량이 많은 불량환경에 대한 적응성 이 높아 예로부터 우리나라에서는 벼 재배가 부적당하거나 냉해의 발생이 쉬운 지역에서 식용피를 재배해 오고 있었 다(Lee, 2010). 제주도 등 일부 농가에서 청예사료용으로 재배되고 있다고 보고하고 있으며, 또한 피는 나트륨 함량 이 높은 간척지에서도 적응력이 높다고 보고하고 있다
(Choi et al., 1991b; Lee, 1981; Shin et al., 2006). 그리고 피는 $\mathrm{C}_{4}$ 식물로 광합성 효율이 높고, 생육기간이 짧아 하 절기 논에서 Biomass 생산에 유리한 식물이다(Cho et al., 2001c). 또한 도입된 피인 Chiwapa와 진주피, 제주피 등 3 종의 피의 생육특성 및 사료 생산성 비교에서 도입종에 비 해 진주피와 제주피가 ha당 $1,700 \mathrm{~kg}$ 정도 더 많은 건물 수량을 얻어 우리나라 기후와 토양조건에는 청예사료용 피 가 적당하다고 Lee (1980)는 보고하였으며, 또한 대부분의 북방형 목초는 7 8월의 고온조건하에서 소위 하고현상 (summer depression)을 일으켜 생육이 정지되고 수량이 감 소되지만, 이에 대해 피는 유리하다고 보고하고 있다(Lee, 1981).

피에 대한 파종량 및 시비량 차이에 대한 생육특성 및 청예수량은 보고되어 있으나(Cho et al., 2001a; Lee et al.,

* Corresponding author: Jung-Joon Lee, Korean Wheat and Barley Industry Development Institute, Suwon 441-857, Korea. Tel: +82-31892-6644, E-mail: leejj2290@daum.net 
1980), 중부지역에서의 파종기의 조만에 따른 생육특성 및 청예수량 변화에 대한 연구가 미미하여 이를 구명하고자 하였다.

\section{П. 재료 및 방법}

본 연구는 2012년부터 2013년 2개년에 걸쳐 경기도 수 원시 오목천동 시험포장에서 실시하였다. 시험재료는 농촌 진흥청 농업유전자원센터에서 분양받은 조생종 유전자원 사료용피 Shirohie millet (IT17069, Echinochloa crus-galli)과 만생종 유전자원 사료용피 제주수집종(IT195422, Echinochloa frumentacea)을 이용하여 파종기를 5월 1 일부터 10 일 간격 으로 6월 21일까지 6회 파종하여 초장, 경수 등 생육상황 과 사료수량 및 사료가치를 비교 분석하였다. 재배방법은 2012 년에는 파종량 $10 \mathrm{a}$ 당 $2 \mathrm{~kg}$ 수준으로 $40 \mathrm{~cm}$ 간격으로 조파하였고, 2013년에는 조간 $30 \mathrm{~cm}$, 주간 $15 \mathrm{~cm}$ 에 주당 2-3립 점파하여 수행하였다. 시비는 수원시 농업기술센터에 토양분석을 의뢰하여 일반벼를 기준으로 하는 3 요소 시비 처방에 준하였으나 질소는 사료용임을 감안하여 $50 \%$ 증비
하였다. 그리고 시험구 배치는 파종기를 주구로 하고 피계 통을 세구로 하는 분할구 배치 3 반복으로 수행하였다.

사료수량은 출수 후 5 7일 경에 예취하여 측정하였고, 사료가치 분석은 2012년은 농업기술실용화재단 비료사료분 석팀에, 2013년에는 천안연암대학 농업기술연구센터에 의 뢰하여 수행하였는데, 각 파종기별로 수확한 시료를 산성 용매불용성섬유(ADF), 중성용매불용성섬유(NDF) 함량은 Georing과 Van Soset법(1970)을 이용하여 분석하였고, 가소 화영양소총량 $(\mathrm{TDN})$ 은 $88.9-0.79 * \mathrm{ADF}$ 로 계산하였으며, 가소 화건물함량 $(\mathrm{DDM})$ 은 미국초지조사료협회의 $\mathrm{DDM}(\%)=$ 88.9-0.779*ADF의 공식을 이용하였으며, $\mathrm{TDN}$ 수량은 건물 수량*TDN (\%)으로 산출하였다(Lee, 2009; Seo et al., 2012).

\section{III. 결과 및 고찰}

조생종 피인 IT170609의 생육상황을 Table 1에서 보면 초장은 파종기가 늦어질수록 작아졌고 2개년 모두 동일한 경향을 보였다. 그리고 수장은 파종기에 따른 변화가 크지 않았다. 파종기에 따른 $\mathrm{m}^{2}$ 당 경수는 2012년에는 차이가 없

Table 1. Changed of heading date, number of culm, fresh and dry weight by different seeding dates in earlyheading type, IT170609 of Barnyard Millet

\begin{tabular}{|c|c|c|c|c|c|c|c|c|}
\hline Year & $\begin{array}{l}\text { Seeding } \\
\text { date } \\
\text { (A) }\end{array}$ & $\begin{array}{l}\text { Plant } \\
\text { height } \\
(\mathrm{cm})\end{array}$ & $\begin{array}{c}\text { Panicle } \\
\text { length } \\
(\mathrm{cm})\end{array}$ & $\begin{array}{c}\text { Number of } \\
\text { culm } \\
\left(\mathrm{No} . \mathrm{m}^{2}\right)\end{array}$ & $\begin{array}{l}\text { Heading } \\
\text { date } \\
\text { (B) }\end{array}$ & $\begin{array}{c}\text { Days from } \\
\text { A to } B\end{array}$ & $\begin{array}{c}\text { Fresh } \\
\text { weight } \\
\text { (MT/ha) }\end{array}$ & $\begin{array}{c}\text { Dry } \\
\text { weight } \\
\text { (MT/ha) }\end{array}$ \\
\hline \multirow{7}{*}{2012} & "May 1 & $177 \mathrm{a}^{*}$ & $13.0 \mathrm{~b}$ & $231 \mathrm{a}$ & July 23 & 83 & $67.1 \mathrm{ab}$ & $\begin{array}{ll}14.0 \quad \mathrm{a} \\
\end{array}$ \\
\hline & May 11 & $179 \mathrm{a}$ & $14.2 \mathrm{a}$ & $288 \mathrm{a}$ & July 24 & 74 & $72.9 \quad \mathrm{a}$ & $13.2 \mathrm{a}$ \\
\hline & May 21 & $166 a b$ & $14.0 \mathrm{a}$ & $294 \mathrm{a}$ & July 29 & 69 & $65.6 \mathrm{ab}$ & $11.1 \mathrm{ab}$ \\
\hline & June 1 & $158 \mathrm{ab}$ & $14.0 \mathrm{a}$ & $279 \mathrm{a}$ & Aug. 4 & 64 & $72.5 \mathrm{a}$ & $11.5 \mathrm{ab}$ \\
\hline & June 11 & $145 \mathrm{bc}$ & $14.8 \mathrm{a}$ & $290 \mathrm{a}$ & Aug. 7 & 57 & $59.6 \mathrm{ab}$ & $8.9 \mathrm{bc}$ \\
\hline & June 21 & $138 \mathrm{c}$ & $12.7 \mathrm{~b}$ & $242 \mathrm{a}$ & Aug. 15 & 55 & $43.1 \quad b$ & $5.6 \mathrm{c}$ \\
\hline & Mean & 160.5 & 13.8 & 271 & Aug. 2 & 67 & 63.5 & 10.7 \\
\hline \multirow{7}{*}{2013} & May 1 & $165 \mathrm{ab}$ & $12.6 \mathrm{a}$ & $180 \mathrm{ab}$ & July 13 & 73 & $49.7 \mathrm{ab}$ & $12.0 \mathrm{a}$ \\
\hline & May 11 & $167 \mathrm{a}$ & $13.6 \mathrm{a}$ & $188 \quad \mathrm{a}$ & July 13 & 63 & $57.2 \mathrm{a}$ & $11.4 \mathrm{a}$ \\
\hline & May 21 & $167 \mathrm{a}$ & $13.1 \mathrm{a}$ & $144 \mathrm{a}$ & July 19 & 59 & 58.6 a & $12.4 \mathrm{a}$ \\
\hline & June 1 & $148 \mathrm{bc}$ & $12.2 \mathrm{a}$ & $141 \mathrm{bc}$ & July 28 & 57 & $41.4 \mathrm{bc}$ & $8.4 \mathrm{~b}$ \\
\hline & June 11 & $148 \mathrm{bc}$ & $12.5 \mathrm{a}$ & $144 \mathrm{bc}$ & July 31 & 50 & $40.7 \mathrm{bc}$ & $7.8 \mathrm{~b}$ \\
\hline & June 21 & $139 \mathrm{c}$ & $12.9 \mathrm{a}$ & $123 \mathrm{c}$ & Aug. 7 & 47 & $32.0 \mathrm{c}$ & $6.1 \mathrm{~b}$ \\
\hline & Mean & 155.7 & 12.8 & 153 & July 26 & 58 & 46.6 & 9.7 \\
\hline \multirow{7}{*}{ Average } & May 1 & $171 \quad \mathrm{a}$ & $12.8 \mathrm{~b}$ & $206 a b$ & July 18 & 78 & $58.4 \mathrm{ab}$ & $13.0 \mathrm{a}$ \\
\hline & May 11 & $173 \mathrm{a}$ & $13.9 \mathrm{a}$ & $238 \quad \mathrm{a}$ & July 19 & 69 & $65.1 \mathrm{a}$ & $12.3 \mathrm{a}$ \\
\hline & May 21 & $167 \mathrm{ab}$ & $13.6 \mathrm{a}$ & 219 a & July 24 & 64 & $62.1 \quad \mathrm{a}$ & $11.8 \mathrm{a}$ \\
\hline & June 1 & $153 \mathrm{bc}$ & $13.1 \mathrm{a}$ & $210 \quad a$ & Aug. 1 & 61 & $57.0 \mathrm{ab}$ & $10.0 \mathrm{~b}$ \\
\hline & June 11 & $147 \mathrm{bc}$ & $13.7 \mathrm{a}$ & $217 \quad \mathrm{a}$ & Aug. 4 & 54 & $50.2 \mathrm{bc}$ & $8.4 \mathrm{~b}$ \\
\hline & June 21 & $139 \mathrm{c}$ & $12.8 \mathrm{~b}$ & $183 \mathrm{~b}$ & Aug. 11 & 51 & $37.6 \mathrm{c}$ & $5.9 \mathrm{~b}$ \\
\hline & Mean & 158 & 13.3 & 212 & July 28 & 63 & 55.1 & 10.2 \\
\hline
\end{tabular}

* Duncan's Multiple Range Test $(a=0.05)$. 
었으나 2013년에는 파종기가 늦어질수록 적어지는 경향을 보였다. 출수기는 파종기가 늦어질수록 늦어지는 경향을 보였으나 파종기부터 출수기까지의 기간은 점차 짧아지는 경향을 보였다. 이처럼 파종기가 늦어진 일수는 51일인데 비하여 파종기에 따른 출수까지의 기간이 짧아진 일수는 26 28일로 파종기가 늦어질수록 출수가 빨라지는 것은 피 의 출수가 단일에 감응함을 알 수 있었다.

조생종 피의 조사료 건물수량은 파종기가 늦어질수록 감 소하는 것으로 나타났으며 2개년 모두 같은 경향을 보였 다. 건물수량이 급격히 감소되는 파종기는 2012년에는 6월 11일 이후부터, 2013년에는 6월 1일 이후부터로 수원을 중 심으로 하는 중부지역에서 조생종 피의 최대 건물수량을 얻기 위해서는 5 월 1 일까지는 파종기를 빨리 하는 것이 유 리하며, 안전한 조사료 수량을 얻기 위해서는 6월 1일 이 전에 파종해야 하는 것으로 나타났다.

만생종 피인 IT195422의 생육상황을 Table 2에서 보면 초장은 파종기가 빠르거나 너무 늦어지면 짧아지는 경향을 보였고, 수장 역시 초장과 같은 경향을 나타내었다. $\mathrm{m}^{2}$ 당
경수는 2012년에는 파종기에 따른 차이가 없었으나, 2013 년에는 파종기가 늦어질수록 적어지는 경향을 보였다.

조생종과 만생종 모두 $\mathrm{m}^{2}$ 당 경수가 2012년에는 파종기 에 따른 차이가 없었으나 2013년에는 6월 1일 파종기 이후 부터 줄어들었다. 그 이유를 살펴보기 위해 2 개년 간 피의 생육기간동안의 기온을 비교해 보았을 때 5 월을 제외한 6 , 7, 8월의 기온은 두 해가 비슷하게 경과하였다(Table 3). 따라서 그 원인을 생육기간동안의 기온의 차이라고 보기보 다는 두 해간의 파종량 차이에 기인한 것으로 생각해 볼 수 있다. 즉 2012년에는 $10 \mathrm{a}$ 당 $2 \mathrm{~kg}$ 수준으로 매우 밀식으 로 파종을 하였고 2013 년에는 조간 $30 \mathrm{~cm}$ 주간 $15 \mathrm{~cm}$ 로 2 3립 점파하여 파종량이 현저히 줄어들게 되어 파종기 지 연에 따른 부적합한 환경에서의 경수의 감소효과가 뚜렷이 나타난 결과라 사료된다.

만생종 피의 출수기는 조생종 피와 비슷하게 파종기가 늦어질수록 늦어지는 경향을 보였으나 파종기부터 출수기 까지의 기간은 점차 짧아졌다. 조생종피의 경우 파종기가 늦어짐에 따라 출수까지의 일수가 짧아진 일수가 26 28일

Table 2. Changed of heading date, number of culm, fresh and dry weight by different seeding dates in lateheading type, IT 195422 of Barnyard Millet

\begin{tabular}{|c|c|c|c|c|c|c|c|c|}
\hline Year & $\begin{array}{c}\text { Seeding } \\
\text { date } \\
\text { (A) }\end{array}$ & $\begin{array}{l}\text { Plant } \\
\text { height } \\
(\mathrm{cm})\end{array}$ & $\begin{array}{l}\text { Panicle } \\
\text { length } \\
\text { (cm) }\end{array}$ & $\begin{array}{c}\text { Number of } \\
\text { culm } \\
\left(\mathrm{No} . / \mathrm{m}^{2}\right)\end{array}$ & $\begin{array}{c}\text { Heading } \\
\text { date } \\
\text { (B) }\end{array}$ & $\begin{array}{l}\text { Days from } \\
\text { A to } B\end{array}$ & $\begin{array}{c}\text { Fresh } \\
\text { weight } \\
\text { (MT/ha) }\end{array}$ & $\begin{array}{c}\text { Dry } \\
\text { weight } \\
\text { (MT/ha) }\end{array}$ \\
\hline \multirow{7}{*}{2012} & May 1 & $179 \mathrm{a}^{*}$ & $22.7 \mathrm{~b}$ & $146 \mathrm{a}$ & Aug. 22 & 113 & $82.9 \mathrm{c}$ & $19.3 \mathrm{bc}$ \\
\hline & May 11 & $212 \mathrm{a}$ & $22.7 \mathrm{~b}$ & $167 \mathrm{a}$ & Aug. 22 & 103 & $101.0 \mathrm{~b}$ & $22.8 \quad \mathrm{~b}$ \\
\hline & May 21 & $223 \mathrm{a}$ & $24.0 \mathrm{a}$ & $133 \mathrm{a}$ & Aug. 25 & 96 & $141.3 \mathrm{a}$ & $28.2 \mathrm{a}$ \\
\hline & June 1 & $211 \mathrm{a}$ & $21.7 \mathrm{~b}$ & $148 \mathrm{a}$ & Aug. 25 & 85 & $122.1 \mathrm{ab}$ & $21.8 \mathrm{ab}$ \\
\hline & June 11 & $161 \mathrm{~b}$ & $14.8 \mathrm{~d}$ & $197 \mathrm{a}$ & Sep. 2 & 83 & $69.4 \mathrm{~cd}$ & $12.7 \mathrm{~cd}$ \\
\hline & June 21 & $141 \mathrm{c}$ & $15.7 \mathrm{~d}$ & $154 \mathrm{a}$ & Sep. 4 & 75 & $47.5 \mathrm{~d}$ & $10.6 \mathrm{~d}$ \\
\hline & Mean & 187.8 & 20.3 & 158 & Aug. 29 & 93 & 94.0 & 19.2 \\
\hline \multirow{7}{*}{2013} & May 1 & $206 \mathrm{ab}$ & $17.9 \mathrm{~b}$ & $116 \mathrm{a}$ & Aug. 13 & 103 & $61.4 \mathrm{~b}$ & $20.7 \quad b$ \\
\hline & May 11 & $212 a b$ & 19.9 a & $127 \mathrm{a}$ & Aug. 14 & 95 & $71.8 \mathrm{ab}$ & $23.4 \mathrm{ab}$ \\
\hline & May 21 & $221 \quad \mathrm{a}$ & $20.7 \mathrm{a}$ & $141 \mathrm{a}$ & Aug. 15 & 86 & $81.1 \mathrm{a}$ & $25.9 \quad \mathrm{a}$ \\
\hline & June 1 & $215 a b$ & $21.9 \mathrm{a}$ & $88 \mathrm{~b}$ & Aug. 20 & 80 & $61.1 \mathrm{~b}$ & $18.9 \mathrm{bc}$ \\
\hline & June 11 & $201 \quad b$ & $20.8 \mathrm{a}$ & $74 \mathrm{~b}$ & Aug. 25 & 75 & $47.3 \mathrm{c}$ & $15.6 \mathrm{c}$ \\
\hline & June 21 & $181 \mathrm{c}$ & $19.4 \mathrm{a}$ & $85 \mathrm{~b}$ & Aug. 27 & 67 & $42.6 \mathrm{c}$ & $14.0 \mathrm{c}$ \\
\hline & Mean & 206 & 201 & 105 & Aug. 20 & 84 & 60.9 & 19.8 \\
\hline \multirow{7}{*}{ Average } & May 1 & $193 \mathrm{ab}$ & $20.3 \mathrm{~b}$ & $131 \mathrm{a}$ & Aug. 18 & 108 & $72.2 \mathrm{bc}$ & $20.0 \mathrm{bc}$ \\
\hline & May 11 & $212 a b$ & $21.3 \mathrm{a}$ & $147 \mathrm{a}$ & Aug. 18 & 99 & $86.4 \mathrm{ab}$ & $23.1 \mathrm{ab}$ \\
\hline & May 21 & $222 \mathrm{a}$ & $22.4 \mathrm{a}$ & $137 \mathrm{a}$ & Aug. 20 & 91 & $111.2 \mathrm{a}$ & $27.1 \quad \mathrm{a}$ \\
\hline & June 1 & $213 \mathrm{ab}$ & $21.8 \mathrm{a}$ & $118 \mathrm{~b}$ & Aug. 23 & 83 & $91.6 \mathrm{ab}$ & $20.4 \mathrm{bc}$ \\
\hline & June 11 & $181 \mathrm{~b}$ & $17.8 \mathrm{a}$ & $136 \mathrm{a}$ & Aug. 29 & 79 & 58.4 c & $14.2 \mathrm{~d}$ \\
\hline & June 21 & $161 \mathrm{c}$ & $17.6 \mathrm{a}$ & $120 \mathrm{~b}$ & Aug. 31 & 71 & $45.1 \quad \mathrm{c}$ & $14.0 \mathrm{~d}$ \\
\hline & Mean & 197 & 20.2 & 132 & Aug. 23 & 89 & 77.5 & 19.5 \\
\hline
\end{tabular}

* Duncan's Multiple Range Test $(a=0.05)$. 
Table 3. Minimum, maximum and mean temperature during growth period of barnyard millet in Suwon

\begin{tabular}{|c|c|c|c|c|c|c|}
\hline \multirow{2}{*}{$\begin{array}{l}\text { Year } \\
\text { Temp. } \\
\text { Month }\end{array}$} & \multicolumn{3}{|c|}{2012 Temp. $\left({ }^{\circ} \mathrm{C}\right)$} & \multicolumn{3}{|c|}{2013 Temp. $\left({ }^{\circ} \mathrm{C}\right)$} \\
\hline & Min. & Max. & Mean & Min. & Max. & Mean \\
\hline May & 13.7 & 25.2 & 19.0 & 12.2 & 23.7 & 17.5 \\
\hline June & 19.2 & 29.2 & 23.6 & 19.0 & 28.8 & 23.5 \\
\hline July & 22.2 & 29.5 & 25.5 & 23.1 & 28.9 & 25.5 \\
\hline August & 24.0 & 31.3 & 27.3 & 23.8 & 32.2 & 27.4 \\
\hline
\end{tabular}

이였으나 만생종 피에서는 36 38일로서 10 일정도 조생종 피에 비해 더 짧아졌다. 이는 만생종의 경우가 단일에 조 생종에 비해 상대적으로 둔감하긴 하지만 짧은 일장 하에 서 생장을 더 오래함에 따른 결과로 사료된다.

만생종 피의 조사료 건물수량은 파종기가 빠르거나 너무 늦은 경우 감소하는 결과를 보였으며 이러한 경향은 2 개년 비슷하였다. 그리고 6월 11일 최대수량을 보인 파종기는 2 개년 모두 5월 21 일이었다. 급격히 수량이 감소하는 파종 기는 2012년에는 6월 11일 이후였으며 2013년에는 6월 1 일 이후였다. 따라서 만생종 피의 경우에 최대수량을 얻기 위해서는 5월 21 일 경에 파종을 하고, 안정된 건물수량을 얻기 위해서는 6 월 1 일 이전에 파종을 해야 한다고 볼 수
있다.

조생종 피는 5 월 1 일까지 파종기를 빨리할수록 조사료 수량이 높아지고 만생종 피는 5월 21일경에 파종할 때 가 장 수량이 높아 두 생태형 간에 차이를 보였으나 절대적 수량은 만생종 피가 어느 파종기에서나 조생종 피에 비해 수량이 높아 실제 재배적 측면에서는 만생종피를 선택하는 것이 유리한 것으로 나타났다.

조생종 피인 IT 170609의 사료가치 성분을 Table 4에서 보면 조단백 함량은 파종기가 늦을수록 증가하는 경향이었 으며, $\mathrm{ADF}$ 함량은 파종기의 차이에 따른 변화가 적었으나 파종기가 아주 늦은 6월 21일 파종에서 다소 낮은 경향을 보였다. $\mathrm{NDF}$ 함량 역시 $\mathrm{ADF}$ 함량과 비슷한 경향을 보였

Table 4. Nutrient values of different seeding dates in early-heading type, IT170609 of barnyard millet for 2 years

\begin{tabular}{|c|c|c|c|c|c|}
\hline Year & $\begin{array}{c}\text { Seeding } \\
\text { date }\end{array}$ & $\begin{array}{c}\text { Crude protein } \\
(\%)\end{array}$ & $\begin{array}{c}\mathrm{ADF}^{1)} \\
(\%)\end{array}$ & $\begin{array}{c}\mathrm{NDF}^{2)} \\
(\%)\end{array}$ & $\begin{array}{c}\mathrm{TDN}^{3)} \\
(\%)\end{array}$ \\
\hline \multirow{7}{*}{2012} & May 1 & 10.2 & 35.9 & 66.0 & 60.5 \\
\hline & May 11 & 9.0 & 36.3 & 69.7 & 57.9 \\
\hline & May 21 & 12.6 & 38.4 & 68.9 & 58.6 \\
\hline & June 1 & 16.0 & 39.6 & 69.0 & 57.6 \\
\hline & June 11 & 16.7 & 38.1 & 68.0 & 58.8 \\
\hline & June 21 & 16.3 & 37.8 & 65.9 & 59.0 \\
\hline & Mean & 13.5 & 38.2 & 67.9 & 58.7 \\
\hline \multirow{7}{*}{2013} & May 1 & 10.3 & 38.1 & 66.2 & 58.8 \\
\hline & May 11 & 11.2 & 37.3 & 65.6 & 59.4 \\
\hline & May 21 & 9.1 & 37.9 & 62.6 & 59.0 \\
\hline & June 1 & 9.8 & 39.5 & 67.6 & 57.7 \\
\hline & June 11 & 9.8 & 39.7 & 66.0 & 57.5 \\
\hline & June 21 & 14.0 & 34.0 & 61.0 & 62.0 \\
\hline & Mean & 10.7 & 37.6 & 64.8 & 59.1 \\
\hline \multirow{7}{*}{ Average } & May 1 & 10.3 & 37.0 & 66.1 & 59.7 \\
\hline & May 11 & 10.1 & 38.3 & 67.7 & 58.7 \\
\hline & May 21 & 10.9 & 38.2 & 65.8 & 58.8 \\
\hline & June 1 & 12.9 & 39.6 & 68.3 & 57.7 \\
\hline & June 11 & 13.3 & 38.9 & 67.0 & 58.2 \\
\hline & June 21 & 15.2 & 35.9 & 63.5 & 60.5 \\
\hline & Mean & 12.1 & 37.9 & 66.4 & 58.9 \\
\hline
\end{tabular}

\footnotetext{
${ }^{1)} \mathrm{ADF}$ : acid detergent fiber, ${ }^{2)} \mathrm{NDF}$ : neutral detergent fiber, ${ }^{3)} \mathrm{TDN}$ : total digestible nutrients.
} 
다. 따라서 $\mathrm{TDN}$ 함량도 6 월 21일 파종에서 다소 높게 나 타났다. 이는 6월 21일 파종구에서는 피의 생육기간이 짧 고 고온에서 생육을 함에 따라 조직의 경화되는 정도가 적 어 작물체가 연약한 이유로 사료적 가치는 높았던 것으로 사료된다.

만생종 피인 IT 195422의 사료가치 성분을 Table 5에서 보면 조단백 함량은 조생종의 경우와 비슷하게 파종기가 늦어질수록 증가하였으나 파종기가 아주 늦은 6월 21일 파 종 시에는 낮아지는 경향을 보였다. $\mathrm{ADF}$ 함량과 $\mathrm{NDF}$ 함 량의 경우에는 조생종의 경우와 비슷하게 파종기가 늦은 6 월 11 일과 6월 21 일 파종 시에 적어지는 경향을 보였으며, $\mathrm{TDN}$ 함량은 높아지는 경향을 보였다. 이는 조생종의 경우 와 동일하게 고온상태에서 짧은 기간 생장함에 따른 작물 체의 조직 경화가 상대적으로 적게 된 것으로 사료된다.

$\mathrm{TDN}$ 수량을 보면 조사료 건물수량과 동일한 경향을 보 여 조생종은 파종기가 빠를수록, 만생종은 5월 21일경의 파종에서 가장 수량이 높아 적정파종기로 판단되며 6월 1 일 이전까지는 파종을 해야 안정적 수량을 얻을 수 있을 것으로 보인다(Fig. 1, Table 6). 그러나 동계조사료 작물을

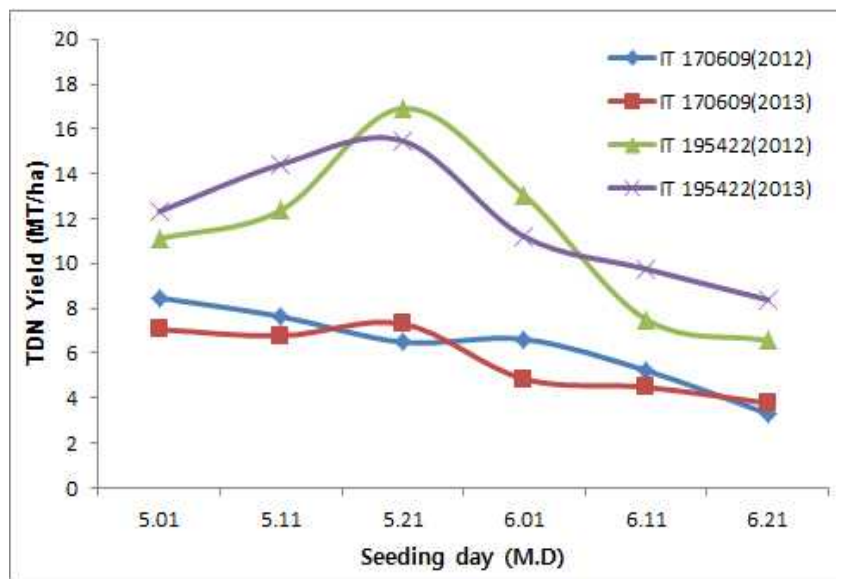

Fig 1. Changed TDN yield by different seeding date.

도입한 작부체계에서는 동계사료작물의 종류에 따라 연중 최대생산을 얻을 수 있는 사료피의 생태형과 파종기를 선 택해야 할 것이다. 따라서 이러한 하계 사료피 + 동계사료 작물의 작부체계 구축에 파종기별 사료피의 수량성과 사료 품질 특성은 유용한 정보가 될 수 있을 것이다.

Table 5. Nutrient values of different seeding dates in late-heading type, IT195422 of barnyard millet for 2 years

\begin{tabular}{|c|c|c|c|c|c|}
\hline Year & $\begin{array}{l}\text { Seeding } \\
\text { date }\end{array}$ & $\begin{array}{l}\text { Crude protein } \\
(\%)\end{array}$ & $\begin{array}{c}\mathrm{ADF}^{1)} \\
(\%)\end{array}$ & $\begin{array}{c}\mathrm{NDF}^{2)} \\
(\%)\end{array}$ & $\begin{array}{c}\left.\mathrm{TDN}^{3}\right) \\
(\%)\end{array}$ \\
\hline \multirow{7}{*}{2012} & May 1 & 10.8 & 39.6 & 71.2 & 57.6 \\
\hline & May 11 & 6.8 & 43.6 & 73.9 & 54.3 \\
\hline & May 21 & 12.9 & 36.6 & 66.0 & 60.0 \\
\hline & June 1 & 14.0 & 36.8 & 68.3 & 59.8 \\
\hline & June 11 & 13.6 & 37.7 & 70.2 & 59.1 \\
\hline & June 21 & 13.5 & 34.1 & 66.3 & 62.0 \\
\hline & Mean & 11.9 & 38.1 & 69.7 & 58.8 \\
\hline \multirow{7}{*}{2013} & May 1 & 6.1 & 37.2 & 67.2 & 59.5 \\
\hline & May 11 & 7.7 & 34.5 & 62.6 & 61.6 \\
\hline & May 21 & 5.4 & 36.9 & 64.6 & 59.7 \\
\hline & June 1 & 6.3 & 37.5 & 66.2 & 59.3 \\
\hline & June 11 & 6.4 & 33.3 & 61.4 & 62.6 \\
\hline & June 21 & 7.8 & 36.7 & 66.2 & 59.9 \\
\hline & Mean & 6.6 & 36.0 & 64.7 & 60.4 \\
\hline \multirow{7}{*}{ Average } & May 1 & 8.5 & 38.4 & 69.2 & 58.6 \\
\hline & May 11 & 7.3 & 39.2 & 68.3 & 58.0 \\
\hline & May 21 & 9.2 & 36.8 & 66.3 & 59.9 \\
\hline & June 1 & 10.2 & 37.2 & 67.3 & 59.6 \\
\hline & June 11 & 10.0 & 35.5 & 65.8 & 60.9 \\
\hline & June 21 & 8.0 & 35.4 & 66.3 & 61.0 \\
\hline & Mean & 9.3 & 37.1 & 67.2 & 59.6 \\
\hline
\end{tabular}

\footnotetext{
1) $\mathrm{ADF}$ : acid detergent fiber, ${ }^{2)} \mathrm{NDF}$ : neutral detergent fiber, ${ }^{3)} \mathrm{TDN}$ : total digestible nutrients.
} 
Table 6. Average of TDN yield of different seeding date in two type of barnyard millet for 2 years

\begin{tabular}{lccc}
\hline \multirow{2}{*}{ Year } & Seeding & \multicolumn{2}{c}{ TDN yield (MT/ha) } \\
\cline { 3 - 4 } & date & $\begin{array}{c}\text { IT170609 } \\
\text { (Early-heading type) }\end{array}$ & $\begin{array}{c}\text { IT195422 } \\
\text { (Late-heading type) }\end{array}$ \\
\hline \hline & May 1 & 7.77 & 11.72 \\
Average & May 21 & 7.21 & 13.40 \\
2012-'13 & June 1 & 6.91 & 16.20 \\
& June 11 & 5.74 & 12.12 \\
& June 21 & 3.86 & 8.64 \\
\cline { 2 - 4 } & Mean & 6.01 & 11.59 \\
\hline
\end{tabular}

IV. 요 약

본 연구는 생태형을 달리한 사료용 피를 이용해서 파종 기를 5 월 1 일부터 10 일 간격으로 6 회 파종하여 생육, 사료 수량 및 사료가치를 경기도 수원 지방에서 검토한 내용은 다음과 같다. 조생종 피의 초장은 파종기가 늦어질수록 작 아졌고, 수장은 파종기에 따른 변화가 크지 않았다. 조생종 피의 조사료 건물수량은 파종기가 늦어질수록 감소하는 경 향을 나타냈다. 중부지방에서 조생종 피의 최대 건물수량 을 얻기 위해서는 5 월 1 일까지는 파종기를 빨리하는 것이 유리하며, 안전한 조사료 수량을 얻기 위해서는 6 월 1 일 이전에 파종해야 하는 것으로 나타났다. 만생종 피의 초장 은 파종기가 빠르거나, 너무 늦어지면 짧아지는 경향을 보 였고, 수장 역시 초장과 같은 경향을 보였다. 만생종 피의 조사료 건물수량은 파종기가 빠르거나, 너무 늦은 경우 감 소하는 결과를 보였다. 따라서 만생종의 경우에 최대수량 을 얻기 위해서는 5 월 21 일경에 파종을 하고, 안정된 수량 을 얻기 위해서는 6월 1 일 이전에 파종을 해야 한다. 조생 종 피는 빨리 파종할수록 조사료 수량이 높아지고, 만생종 피는 5월 21일경에 파종할 때 가장 수량이 높아 두 생태형 간의 차이를 보였으나, 절대적 수량은 만생종 피가 어느 파종기에서나 조생종 피에 비해 수량이 높아 실제 재배적 측면에서는 만생종 피를 선택하는 것이 유리한 것으로 나 타났다. 조생종 피의 조단백 함량은 파종기가 늦을수록 증 가하는 경향이었으나, $\mathrm{ADF}$ 함량과 $\mathrm{NDF}$ 함량은 파종기의 차이에 따른 변화가 적었다. 만생종 피의 조단백 함량도 파종기가 늦어질수록 증가하였으며 $\mathrm{ADF}$ 함량과 $\mathrm{NDF}$ 함량 의 경우에는 조생종 피의 경우와 같은 경향을 보였다. $\mathrm{TDN}$ 수량은 조사료 건물수량과 동일한 경향을 보여 조생 종 피는 파종기가 빠를수록, 만생종 피는 5월 21 일경의 파
종에서 가장 수량이 높아 적정 파종기로 판단되며, 두 생 태형 모두 6월 1일 이전까지는 파종을 해야 안정적 수량을 얻을 수 있다. 동계 조사료작물을 도입한 작부체계에서는 동계작물의 종류에 따라 연중 최대생산을 얻을 수 있는 하 계 사료피의 생태형과 파종기를 선택해야 할 것이다. 따라 서 이러한 하계사료피 + 동계사료작물의 작부체계 구축에 파종기별 사료피의 수량성과 사료품질 특성은 유용한 정보 가 될 수 있을 것이다.

$$
\mathrm{V} \text {. 사 사 }
$$

본 연구는 2012년 2013년 농촌진흥청 공동연구과제 지 원에 의해 수행되었다.

\section{REFERENCES}

Cho, N.K., Boo, C.H., Kang, Y.K. and Cho, Y.I. 2001a. Effects of nitrogen rate on agronomic characteristics, forage yield, and chemical composition of Japanese millet. Journal of Korean Animal Science \& Technology. 43:259-266.

Cho, N.K., Kang, Y.K. and Boo, C.H. 2001b. Effects of nitrogen application on agronomic characteristics, forage yield, and chemical composition of Japanese millet. Journal of Korean Animal Science \& Technology. 43:253-258.

Cho, N.K., Kang, Y.K., Song, C.K., Ko, Y.S. and Cho, Y.I. 2001c. Effects of seeding rate on forage yield and chemical composition of Echinochloa crusgalli var. frumentacea (Roxb) Wight in Jeju region. Journal of Korean Grassland Science. 21:225-232.

Choi, B.H., Park, K.Y. and Park, R.K. 1991. Salt tolerance and green fodder and grain yields of barnyard millet (Echinochloa crusgalli var. frumentacea). Korean Journal of Crop Science. 36:249-253.

Chun, W.B. 1976. Studies on the growth and nutrient metabolism of Japanese millet(Echinochloa crusgalli var. frumentacea Trin) Korean Journal of Animal Science. 18:505-511.

Goering, H.K. and Van Soest, P.J. 1970. Forage fiber analysis. USDA Agronomic Handbook No. 379, Washington, D. C.

Lee, H.W. 1981. Studies on the production and Management of Japanese millet (Echinochloa crus-galli) for summer forage. - I . Agronomic characteristics and yield performance of three Japanese millet cultivars. Korean Journal of Animal Science. 23: 264-269.

Lee, H.W. and Kim, D.A. 1980. Effect of seeding rates and nitrogen fertilization on the growth, chemical composition and forage yield of Japanese barnyard millet Echinochloa crusgalli var. frumentacea (Roxb) W.F. Wight. Korean Journal of Animal 
Science. 22:83-92.

Lee, Y.S. 2010. Studies on agronomic characteristics and utilization of Baranyard millet (Echinochoa spp.) Chungbuk University press $10-15$.

Seo, S., Kim, W.H., Jung, M.W., Lee, S.H. Kim, C.M., Choi, J.H., Kim, J.S., Kim, H.Y. and Lee, J.K. 2012. Forage quality and production of Phragmites communis as a native grass according to growth stages. Journal of The Korean Society Grassland and
Forage Science. 32:109-116.

Shin, J.S., Kim, W.H., Lee, S.H. and Shin, H.Y. 2006. Comparison of dry matter yield and feed value of millet varieties in the reclaimed tidelands. Journal of The Korean Society Grassland and Forage Science. 26:215-220.

(Received October 8, 2013/Revised November 19, 2013/Accepted November 25, 2013) 